Kamila Sara Kowalska

Nicolaus Copernicus University (Poland)

\title{
The Rule of Law in Poland
}

\author{
Book review: Łukasz Bojarski, Krzysztof Grajewski, Jan Kremer, Gabriela Ott, \\ Waldemar Żurek, Konstytucja. Praworzadność. Wtadza sq̨downicza. Aktualne \\ problemy trzeciej władzy w Polsce, Warsaw 2019, pp. 616.
}

Undoubtedly, the observance of the law, the independent judiciary, the action of institutions based on the principle of legalism, respect for Human Rights, use of legislative procedures to adopt laws, etc., are determinants characterizing most of the modern democratic states, including Poland since 1989, which has joined the ranks of countries representing democratic values. So far Poland has used its potential so well that it has been said that Poland is a great example of development and building democracy. At the present time, political scientists, lawyers, civil organizations and the international environment are asking themselves, where is Poland currently located on the axis of State regimes? Is it still possible to call it a democratic state? How far-reaching are changes in Polish legislation and what will be their consequences? Will the battle for the rule of law in Poland bring consequences for Europe?

Twenty-nine experts in law, political science and sociology who are the authors of the publication „Constitution. The rule of law. Judicial authority. Current problems of international power in Poland", published by Wolters Kluwers publishing house, edited by Łukasz Bojarski, Krzysztof Grajewski, Jan Kremer, Gabiel Ott and Waldemar Żurek, have attempted to answer the above questions and other, more complex ones. As mentioned in the introduction, the rule of law applies to all citizens of the Republic of Poland. The book is mainly addressed to students and academics who are truly interested in the current political and legal situation in the country. The publication has a rich theoretical content supported by numerous examples from the contemporary political scene and can be an interesting publication for a better understanding of the dispute over the judiciary, for people outside the academic circle. 
The publication was split into four parts, which, from the perspective of the monograph, constitute a uniform whole. The first part of the book „Constitution. The rule of law” has been devoted to the fundamental rule of law. It is presented from three main perspectives, i.e. in the first parts its author presents the competence of the President of Poland to proper observance of the Constitution by the constitutional organs (p. 15). In the second part, Ireneusz Kamiński presents EU values for the rule of law and protection of its mechanisms. The author shows two essential mechanisms for the protection the rule of law - juridical practice by the CJEU and the courts of the European Union members, and second, a political mechanism used by European Commission (p. 35). Finally, in last part a writer accurately shows that every democratic country needs for proper functioning a close cooperation between legislators, judges and the scientific community, in order to guarantee the highest quality of the law (p. 65). As a consequence, the first section of the monograph systematizes the knowledge about the political and legal system functioning in Poland.

The second part, entitled "Constitution. Judical power", is the most comprehensive part of the monograph, because it discusses the three essential elements of the judicary in Poland. The first considerations concern the National Council of the Judiciary. Małgorzata Niezgódka-Medek discusses the functioning of the constitutional and public body against the changes that occurred at the turn of 2017 and 2018 (p. 93), while Anna Rakowska-Trela interprets and assesses the constitutionality of the individual changes that have occurred with amendment in National Council of the Judiciary act (p. 107).

In this part, a separate consideration was devoted to the changes occurring in the Polish judiciary, i.e. the Constitutional Tribunal of the Republic of Poland, the Supreme Court in Poland and in the ordinary courts. With regard to the Tribunal (p. 125), Maciej Pach, in his considerations, presents in a chronological manner organizational changes in the Constitutional Tribunal and also cites not known facts about previous trials implementation of changes in the Tribunal organization by the Polish political party Law and Justice. Agnieszka Grzelak took a similar design of the considerations. She discusses the unsuccessful changes made by the Sejm of the Republic of Poland of the $8^{\text {th }}$ term in the Supreme Court organisation (p. 156). The failure of changes in laws has its background in the activities of the EU institution, which are described in the first part of the book (p. 35). Then, three representatives of the legal Environment and the Helsinki Foundation for Human Rights, in their article present the situation of courts of general jurisdiction in Poland. Also, their text show the issue of strengthening the role of the Polish Minister of Justice, which, after the statutory changes, had an unrestricted right to interfere with the appointed judges (p. 182). The study carried out by the authors seems so interesting for this reason, that it was conducted not only on the basis of statistics made available by the Ministry of Justice, but also of individual interviews with the judges who were directly affected by the reform Judiciary. The last article provides an analysis of the sociological and political-legal activities of communication of courts with the public, during a period of intense struggle for free judiciary. This article is not only a collection of statistical values relevant to the phenomenon, but also 
a solid basis for further research into the communication of courts with individuals and public authorities, as the author precisely defines the communication model, the addressees, the communication levels and the communication strategy (p. 197).

The final element of publication in the second part is the issue of judges. The considerations starts from the updated Judge Decalogue, created in 1993 by the former Ombudsman and judge of the Polish Constitutional Tribunal (p. 249). The updated decalogue created by Ewa Łętowska shows for judges that in curently political and legal situation they need to be guided by the general principles accordance with the principle of the rule of law. Thereafter, Dariusz Mazur - judge at the General court in Cracov - in a multi-faceted manner presents the implications of the great reform of the judiciary started in poland in 2015 (p. 261). In a comprehensive manner, he presents the changes introduced by the new laws and also defines the resulting risks and procedural weaknesses. At the same time, he assesses the effectiveness of the courts, which, after making the changes, are subordinated to the Polish political party the Law and Justice. In another article of this part, the three sociologists, researchers from Court Watch Polska, present the results of the study carried out on 366 candidates selected by the National Council of the Judiciary. This study relates to the selection process for candidates for vacancies between 2014-2017 (p. 368). The authors of this study present the profile of the candidate for courts judge, based on his age, experience, profession, and qualification. The last text is a comparative analysis of the models of judicial training in Poland and Italy (p. 387). The authors of the paper first classify the models of selection of judges and make them characterize, in the next part of the work, the authors compare the mixed model (Poland) and competition model (Italy), and try to choose this model which guaranteeing the independence of the election of judges - unfortunately, none does not fully meet this criterion.

The penultimate part of the monograph was devoted to the judiciary in an international context. The third part consists of five works. First paper is an extension of the deliberations made in the first part of the monograph. Authors present the competences of the EU judicial authority of the CJEU to ensure that Member States comply with the law within the meaning of the acquis (p.403). The authors have made observations in the context of the violation of the rule of law by Poland and Hungary. Then Joanna Wiśniewska-Kołodziejzyk presents the existing and possible consequences of non-observance of the rule of law in Poland (p.431). The negative implications that the author says in her article relate to the common policy of the area of freedom, security and justice, especially in the context of European Arrest Warrant which was contested by the courts of the Member States in relation to the current situation in Poland. About another kind of negative consequences of non-observance of the rule of law, in his paper writes Tomasz Tadeusz Koncewicz, who not only explains the procedure of preliminary rulings, but also indicates their significance for further European integration (p. 486). The author clearly emphasizes that the failure to comply with the law in one Member State may affect disintegration EU, for Poland, it may be a step towards the „POLEXIT”. The topic of the preliminary ruling is maintained by the authors of the next 
paper contained in the monograph (p. 523). They shall make the findings of fact, in relation to amendments to the laws of the Supreme Court and the Supreme Administrative Court, and at the same time indicate fundamental violations of these amendments in regard to European law (European Convention on Human Rights, Charter of Fundamental Rights of the European Union, Case-law of the Court of Justice, European Union acquis law). The authors also submit the content of the questions referred for a preliminary ruling, but do not make for them wider comments. The last paper in third part concerns the definition of courts at the European Union level (p. 565). The author, in the first part of his deliberations, analyzes the court definitions appearing in the Case-law of the Court of Justice and secondly, responds to the question: whether the changes in the Polish judiciary will contribute to the redefinition of the judiciary at EU level?

Fourth, the last part, is the so-called Varia, which consists of two texts. The first discusses the draft law on disclosure public life (p.583) and the second presents the history of the changes occurring in the quarterly newspaper „Krajowa Rada Sądownictwa” (p. 597). Monograph is closed by information about authors and editors (p. 611).

Summarizing, as the authors of the book observe, it was not possible to analyze all current solutions in relation to the rule of law. However, in this book are raised the most important problems for Polish courts and importance of the constitutional rule of law. Of course, it was not possible to raise all current problems, because this is justified in still ongoing term of Sejm, as well as the the CJEU's still-pending matters relating to the Polish judiciary and the procedure under Article 7 TEU launched by European Union for the first time in history. It is therefore worth to follow the scientific achievements of authors of this publication, because they successively publish scientific articles about changing situation of Polish courts. Lastly, it should be reiterated that the reviewed book is a significant position for persons who are working with Polish constitutional law, and those who investigate the field of law, political system, international relations and European studies.

\section{Author}

\section{Kamila Sara Kowalska}

MA, kamila.sara.kowalska@icloud.com - Nicolaus Copernicus University 